\title{
Impact of IAS 12 on Deferred Taxes Regulation in the Czech Republic ${ }^{\#}$
}

\author{
Marcela ŽÁROVÁ*
}

\section{Introduction}

Investigating the impact of IAS 12 on deferred taxes regulation in the Czech Republic, it has to be mentioned the regulatory policy that has been realized over last 20 year by regulatory institutions in Europe. The policy is called harmonization, the process of increasing the compatibility of accounting practices by setting bounds to their degree of variation. On the other hand, standardization appears to imply working towards compatibility has been achieved. However, within accounting, the words have almost become technical terms, and one cannot rely upon the normal differences in meanings (Nobes, 2010). Process increasing compatibility of accounting information seems to be a very useful process. It is said that IFRS brings positive impact on the quality of local accounting rules. Within each country, local regulations govern, to a greater or lesser degree, the issue of financial statements. Such local regulations include accounting standards which are promulgated by the regulatory bodies and/or the professional accounting bodies in the countries concerned. ${ }^{1}$ Despite the harmonization process, there may be systematically different patterns of accounting behavior applicable to various groups of countries (Radebaugh et al., 2006).

The article dealt with impact of IAS 12 on deferred taxes in the Czech Republic, where local regulations include accounting standards only by

\footnotetext{
\# The article is processed as an output of a research project Development of Financial and Accounting Theory and its Application in Practice from Interdisciplinary Point of View (registered number MSM 6138439903).

* Doc. Ing. Marcela Žárová, CSc. - Associate professor; Department of Financial Accounting and Auditing, Faculty of Finance and Accounting, University of Economics, Prague, W. Churchill Sq. 4, 13067 Prague 3, Czech Republic; <zarova@vse.cz>.

1 International Financial Reporting Standards: Preface to Statements of International Accounting Standards; part Accounting Standards (art.8), 2009 International Accounting Standards Committee Foundation (IASCF).
} 
names, but not as an output of regular due process and which are not issued by the professional accounting body at all, not even partially.

Czech Republic belongs to the codified Roman law system. Characteristic features of the accounting regulatory system in continental European countries that are developed in this law environment, is that law specifies the rules in a great detail. Financial reporting regulated by law is too detailed on one hand and on the other hand, most legislators are not well informed about accounting concepts and technicalities of financial reporting. There is a danger that provisions of the law will be inappropriate.

Naturally this regulatory system of accounting, the system where the Accounting Act is on the top of the regulatory hierarchy, is supplemented and completed by a number of other rules, in the case of the Czech Republic, issued by the same institution of the government that provides the Act, the Ministry of Finance.

The regulation of the financial accounting and reporting in the Czech Republic, in the early nineties, has been developed under the above said circumstances, where a tax orientation of accounting existed. At the beginning of nineties of the last century external reporting has been largely invented for the purpose tax base determination. In such circumstances, there may be little motivation for companies to publish financial information. The government has to intervene to oblige companies to do so. The form of such intervene in the hands of the government was the law only. Another characteristic feature of the accounting regulatory system is its connection to the tax rules. Rules used to compute taxable profit were introduced directly into the accounting rules in order to simplified consequent process of revising accounting data by financial authorities.

The first Accounting $\mathrm{Act}^{2}$ (hereafter the Act) was approved by the Czech Parliament in 1991, commencing the process of transition from a centrally planned economy to a market economy. In May, 2004, the Czech Republic joined the European Union (EU). Becoming a member of the EU has been crucial to speeding up reform of the Czech accounting system (Žárová, 2006, 2008). As a member, the Czech Republic is committed to requiring its listed companies to comply with international

2 Accounting Act No 563/1991 Coll. as amended by Act No 495/2005 Col. 
financial reporting standards in their consolidated financial statements at least. The Czech accounting system demonstrates the consequences of the European Commission's decision to apply the IAS/IFRS at the national level. But what stayed unclear was how to deal with the July 2002 Regulation of the European Union on the application of IFRS and to what extent this requirement will be extended to other companies.

Accounting practices were reformed to ensure that new laws were consistent with those of the European Community (EC), so as to facilitate transition to full membership. True and fair view principle was newly established in the Czech accounting. New legislation was therefore influenced by EC accounting practices and IFRS since 2005.

\section{Background for IFRS implementation into the Czech accounting system and impact of IFRS on accounting system}

Over last thirty years, European countries tend to harmonize reported accounting information. Requirements set out in Directives regulated accounting issued in the period started in 1978 till 1991, couldn't ensure comparability of financial reporting in publicly traded Community companies and the high level of transparency of accounting information, there was a requirement to apply a single set of high quality international accounting standards for the preparation of their financial statements. In 2000, the Commission published its Communication on "EU Financial Reporting Strategy: the way forward" in which it was proposed that all publicly traded Community companies prepare their consolidated financial statements in accordance with one single set of accounting standards, namely International Accounting Standards (IAS), at the latest by the year 2005. In the Communication, there were mentioned consolidated financial statements only. In the proposed Regulation on the application of IAS, Member States had an option to permit or require publicly traded companies to prepare annual accounts in conformity with adopted international accounting standards. Regulatory rules were approved by the European parliament as Regulation (EC) No 1606/2002 of the European Parliament and of the Council of 19 July 2002 on the application of international accounting standards.

European strategic decision has impact on accounting regulatory scheme in the Czech Republic. A new phenomenon appears in accounting 
rules in the Czech Republic. From the historical overview it is known that the accounting regulatory body - Ministry of Finance in the Czech Republic changed from year to year procedures concerning rules according those accounting units were allowed to prepare financial statements in compliance with IFRS. Here is an overview of main facts:

In the period covering 1991-2002, "In addition to financial statements prepared in compliance with the Act on Accounting, accounting units may also provide accounting information those are prepared in compliance with IFRS or other internationally recognized accounting principles.".

In the period covering the year $\mathbf{2 0 0 3}$, there was no change in using IAS from previous amendment of the Act on Accounting and accounting units were allowed to use besides domestic rules IAS or other internationally recognized accounting principles.

In the period starting in the year 2004 till present, there was substantial change in using and implementation of IFRS. The year 2004 became crucial historical moment in the existence of the Czech Republic, also in accounting regulation. In May, 2004, the Czech Republic joined the European Union (EU). Adoption of the 2002 EU Regulation on the application of IFRS had fundamental effects on further development of accounting rules in the Czech Republic. Since joining the EU all listed companies shall prepare at least their consolidated financial statements in accordance with IASC standards by 2005 at the latest..The Accounting act dealing systematically with obligation to use of IFRS was issued firstly in the year 2004 .

How this regulation was realized in the Czech accounting system? Implementation of article 4 of EC Regulation into Act in the Czech Republic was as followed: The Act was amended by a new article again in the section 19 called "Balance sheet day", subsection 9. Accepted text of the law in the year 2002 was: "In addition to financial statements prepared in compliance with the Act on Accounting, accounting units may also provide accounting information those are prepared in compliance with IFRS or other internationally recognized accounting principles." Following text replaced subsection 9 as of 1 May 2004, at the date of the Czech Republic's accession to the European Union. The replaced subsection 9 stated: "Accounting units (accounting entities) which are business companies issuing securities listed on a regulated 
market of securities (i.e. are publicly- traded companies) in the European Union's Member States shall apply international accounting standards as governed by the European Community's law to keeping their accounts and preparing their financial statements. For the purpose of this Act, "regulated market in the Czech Republic" shall mean a public market pursuant to another Act. Exact wording of the law (Accounting Act No 563/1991 Coll. as amended by Act No 437/2003 Col.) is not only to meet obligation of companies to prepare consolidated accounts in conformity with the international accounting standards but also to keep their accounts.

\section{Deferred taxes in Czech accounting system}

While the Accounting Act that set out the general principles to be applied remained unchanged since July 1, 1994, the Chart of Accounts and the detailed guidance notes on the Accounting Procedures for Business were subject to many minor amendments that went into effect at various times from 1994 to 2002 . The main characteristic of this period is accounting regulation that could be best described as regulation without hierarchy, a "legal level," or one-level accounting regulation..From a legal point of view, accounting regulation consisted of the Act only. The Ministry of Finance issued detailed Regulatory guidance for accounting which consisted of a chart of accounts and accounting procedures. Even though Regulatory guidance for accounting was not part of the Act, it became obligatory as it was strictly required by tax authorities in the Czech Republic.

During this period the issue of deferred taxes was opened for the first time. However, the whole procedure was extremely limited as for the accounting entities referred to and as for the scope of timing differences giving rise to deferred taxes too. Regulatory guidance for accounting contented procedures concerning deferred taxes.

Only entities in a group accounted for deferred taxes. Moreover, only the differences between taxable income and accounting profit arising from any different between tax and accounting depreciation of both tangible and intangible long-term assets were title for deferred tax recognition. This was rather unique situation and it was criticised by accounting practitioners. Firstly only entities in group were obliged to report deferred taxes and secondly only when differences between taxable 
income and accounting profit arising from any different between tax and accounting depreciation of both tangible and intangible long-term assets. Despite the criticism, companies fulfilled only the statutory requirements. With respect of this procedure, only entities in group provided users of financial statements with true and fair view.

The Act did not mention any method, but it could be deduced, from the recognition of timing differences and from the applicability of future tax rates, that it was using the income statement liability method. Moreover, the outcome deferred tax asset or deferred tax liability was presented in the balance sheet either as a current asset or a current liability. Deferred tax recognition as a short-term balance items are against principles in any accounting standards. The deferred tax asset was to be recognised only if there were no doubts about its future utilisation as the consequence of the principle of conservatism.

Another major change happened during the period 1990-2002. In January 2001, the Accounting Act together with the Provision of the Ministry of Finance was amended in order to bring the Czech legislature closer to the IAS. The scope of deferred tax accounting was broadened and encompassed not only the timing differences arising from different tax and accounting depreciation, for which the recognition was compulsory, but also from other sources: for example product warranty costs, provisions, valuation allowances and loss carried forwards, which were to be recorded at an entity's discretion.

Another significant change was the introduction of the balance sheet liability method for the accounting of deferred taxes on the first-time adoption, but only in this one moment! Again this was not explicitly stated in the Act or Regulatory guidance for accounting, for that matter, but was evident from the way in which the carrying amounts of individual items were regarded.

Only a year later, in January 2002, the Regulatory guidance for accounting (which was in force since 1993) was superseded by a new one $^{3}$ which represented a radical change from the previous requirements of section $\mathrm{X}$ dealing with deferred taxes. It extended the number of entities for which recognising deferred taxes became mandatory: not only the entities forming a group, but also those which had to have their

3 The Provision of MF No. 281/89 759/2001. 
financial statements audited. The others were allowed but not required to account for deferred taxes (Filinger, 2009).

Companies which has obligation to prepare financial statement in compliance with IFRS has obligation to keep their accounts in compliance with IFRS as well. IFRS substitute domestic rules completely. The hierarchy of domestic rules consists of Act on Accounting, Decrees ${ }^{4}$, Czech Accounting Standards ${ }^{5}$. Companies either use IFRS or Czech rules for keeping their accounts and for reporting in financial statements.

There are three groups of accounting entities existing in the Czech accounting system. Respecting legal and organizational aspect of division accounting entities, there are existing groups from companies to sole traders according to used rules in the Czech accounting system. First group covers large companies listed on capital market, their financial statements are audited. This group is obliged to use IFRS for keeping accounts and preparing financial statements. Accounting entities belonging into the second group keeping their accounts and prepare financial statements in compliance with Czech accounting standards. This group of accounting entities covers audited accounting entities as well as entities those haven't requirement to be audited. Entities in this group are not allowed to use IFRS either for keeping accounts or preparing financial statements. The third group covers small companies and sole traders. Even if the accounting entity is a company, these companies declared as small companies has not obligation to be audited and they are not allowed to use Czech accounting standards. They must keep accounts and prepare their financial statements in compliance with simplified double entry bookkeeping. Sole traders prepare cash based- bookkeeping primarily for the tax purposes.

Division of accounting entities in the Czech Republic is rigid. Groups of accounting entities are strictly stated in the Act, Decrees and Czech accounting standards obligations of different group of accounting entities and there is also stated which set of rules are compulsory and on the other hand which are prohibited to be used.

4 Decree on Accounting for Business No 500/2002 Col. as amended by Decree No. 472/2003Col., 397/2005 Col., 349/2007 Col. And 469/2008 Col.

5 Czech Accounting Standards 1-23 in effect as of January 1, 2009, issued by the Ministry of Finance in compliance with article 36 of Accounting Act No 563/1991 Coll. as amended by Act No 495/2005 Col. 
In January 2002, the second major change concerning the deferred tax method used. There was move from the income statement to the balance sheet liability method, and so from timing to temporary differences. The entity is required to recognise deferred tax liability or asset for all taxable and deductible temporary differences. Deferred tax asset is recognised only to the extent that it is probable that future taxable income will be available and the only relevant source of the future taxable income is that of the reversals of taxable temporary differences relating to the same taxation authority and reversing in the periods to which the deductible temporary differences and/or losses can be carried back or forward.

First-time application rule was introduced, under which an entity has to divide the resulting amount of deferred tax into two parts depending on their relation to the current and prior periods. In compliance with the division the deferred tax into current and prior period, to credit or charge them to current profit or loss and to retained earnings, respectively. This procedure should assure not to distort the amount of accounting profit or loss for the period. Any further changes in the method of accounting or tax consequences of capital transformations should also have been recognised directly in stockholders' equity. Relevant information concerning this fact should be disclosed in the notes to the financial statements.

Deferred tax assets and deferred tax liabilities balances were moved from current assets and current liabilities to long-term provisions. To long-term liabilities (not provisions, where they should be recognized) and to receivables those are divided into long-term and short term ones; into long-term receivables.

The structure of accounting regulation for the year 2003 was temporary, as regulatory guidance for accounting described above had to be replaced by National Accounting Standards, by the end of 2003. The main reasons for this fundamental change of accounting regulation were preparation for membership in the EU. In compliance with the EU acquis and the influence of the National Accounting Council, accounting reform started to be realized. The result was another sequent step in rebuilding the regulatory system..Decrees issued by the Ministry of Finance became part of the regulatory system. The structure of accounting regulation for the year 2003 differed from previous one and consisted of two levels of accounting regulations. 


\section{Accounting Act}

The Accounting Act as amended, effective as of January1, 2003 differed from the prior amended Act in few requirements. There was no change in using IAS under the amended Act.

\section{Decrees}

Seven new accounting decrees covering different sectors of the economy were issued (general business entities, banks, insurance companies etc). The substance of these decrees was expressly stated by the Act and involved charts of accounts and the layout of the financial statements. As the other Decrees covered accounting methods only, there was a need for leaving the regulatory guidance for accounting in effect until the end of 2003. Regulatory guidance for accounting procedures gave detailed bookkeeping rules. This arrangement existed until the end of 2003.

Layouts of the balance sheet and income statement became part of the decrees from 2003. An option for accounting entities was provided as to the layout of the income statement. Entities could determine prepare income statements with classification by the nature of expenses or the function of expenses. There were still no options for balance sheet layout. On the other hand, important changes were implemented to the chart of accounts, which became mandatory, but have been more flexible since 2003.

\section{Regulatory guidance for accounting}

Regulatory guidance for accounting was used during the year 2003 for the purpose of bookkeeping rules and other provisions not included either in the Act or Decrees. The contents of the notes to the financial statements and data to be published from financial statements were regulated temporarily by regulatory guidance for accounting until the end of 2003.

Changes to the regulatory framework were completed as of January 1, 2004. Regulatory framework was enlarged into three separate levels. Czech Accounting Standards superseding the Regulatory guidance for accounting came into force. A new phenomenon in Czech accounting, Czech Accounting Standards, was introduced by the legislator. There is a 
separate article in the Act determining who is allowed to develop National Accounting Standards. The article determines Ministry of Finance or any legal entity selected in public tender.

In January 20004, Czech Accounting Standards came into force. Czech Accounting Standards superseded the Provision of the Ministry of Finance.

\section{Deferred taxes regulation in the Czech accounting system}

It is said that hierarchy of the legal regulation is used in the following pattern. At the top of the regulatory hierarchy, law is placed, followed by Decree and Czech Accounting Standards. Standards are to be used only if the Act or Decree does not cover the issue.

\subsection{Deferred taxes in Act on Accounting and Decree on accounting for business entities}

The Act on Accounting doesn't mention deferred taxes at all. The first reference to deferred taxes is in the Decree on accounting for business entities. Separate Czech accounting standard contents procedures concerning deferred taxes.

Decree on accounting for business entities describes the deferred taxes as a special accounting method. The section 59 called method of deferred tax is divided into 6 separate parts which concern method used, deferred tax calculation, used tax rate, states the fact that balance sheet aspect of liability method is used based on temporary differences, conditions for deferred tax liability and deferred tax asset recognition, procedure of deferred tax first time recognition. In spite of the fact that this part is called "deferred tax method", the method is not explained here at all, the method is only entitled.

The first part describes that the deferred tax shall be account for and reported by accounting entities belonging into one consolidation group and by all accounting entities preparing their financial statements in the full format /section 18(3) of the Accounting Act/. Other accounting entities shall determine whether they will account for deferred tax and report it in their financial statements. 
The second part describes the way of deferred tax calculation and called used method identically as in the IAS 12. In compliance with IAS 12 , the decree uses balance sheet liability method. As explained in the IAS 12, the original IAS 12 required an entity to account deferred tax using either the deferral method or a liability method which is sometimes known as the income statement liability method. IAS 12 (revised) prohibits the deferral method and requires another liability method which is sometimes known as the balance sheet liability method. In this part of the decree, there is a stress on the fact that the calculation of deferred tax shall be based on the liability method arising from the balance sheet approach. The decree explains the liability method as "the procedure when deferred tax in relation to a profit or loss ascertained in accounting shall be claimed in a future period, and therefore the tax rate in effect in such a future period shall be used for the tax calculation when the tax liability or tax asset is going to be claimed." There is a note concerning the practical way of calculating the deferred tax, "where this future tax rate is not known, the tax rate in effect in the subsequent accounting period shall be used".

The part number three concentrates upon the fact that liability method which theoretically has two different aspects uses for deferred tax recognition in the Czech accounting, the balance sheet one. The third part of the decree describes that "The balance sheet aspect means that the liability method pursuant to part (2) of the decree is based on temporary differences which are the differences between the tax base of assets, or (if relevant) liabilities, and the amount of assets, or (if relevant) liabilities, as shown in the balance sheet". Here the term temporary differences are mentioned firstly, but no other explanation than the note above is written. Moreover there is not mentioned any relation between timing differences determined in accordance with income statement liability method at all. The income statement liability method focuses on timing differences, whereas the balance sheet liability method focuses on temporary differences. There should be add that timing differences are differences between taxable profit and accounting profit that originate in one period and reverse in one or more subsequent periods. In addition to this very short explanation, there should be introduced proper explanation of temporary differences that temporary differences are differences between the carrying amount of an asset or liability in the statement of financial position and its tax base. And there should be included division of differences in compliance with IAS 12 into: 
a) taxable temporary differences, which are temporary differences that will result in taxable amounts in determining taxable profit (tax loss) of future periods when the carrying amount of the asset or liability is recovered or settled; or

b) deductible temporary differences, which are temporary differences that will result in amounts that are deductible in determining taxable profit(tax loss) of future periods when the carrying amount of the asset or liability is recovered or settled.

The Czech decree on deferred taxes continues with statement "The tax base of such assets, or (if relevant) liabilities, shall be the value of these assets, or liabilities, which can be claimed for tax purposes in the future." In this part, tax base of an asset or tax base of a liability is firstly mentioned but there is no definition of newly introduced terms. IAS 12 uses definition for tax base of an asset or tax base of a liability as "the amount attributed to that assets or liability for tax purposes."

Part number 4 - Deferred tax asset or deferred tax liability shall be calculated as follows: the resulting difference shall be multiplied by the income tax rate, as prescribed by the Income Taxes Act. When the tax rate is amended, the balance sheet in the deferred tax account must be recalculated and the recognized difference should be charged on an account in account group 59 - Income tax expense, transfer accounts and income tax provision. ${ }^{6}$ This part could be better understood if there is a statement on general level that deferred tax assets and liabilities shall be measured at the tax rates that are expected to apply to the period when the asset is realised or the liability is settled, based on tax rates (and tax laws) that have been enacted or substantively enacted by the end of the reporting period.

Part number 5 states that the accounting entity shall always account for a deferred tax liability and will account for a deferred tax asset, taking into consideration the prudent concept. This part contents only this statement without any details in respect of reassessment unrecognised deferred tax assets. It is usual, that at the end of each reporting period, an entity should reassesses unrecognised deferred tax assets. The entity recognises a previously unrecognised deferred tax asset to the extent that

6 Numbers of accounts are compulsorily in the Czech Republic in respect of the numbering of classes in the Chart of Accounts and nominal accounts in the group accounts. This practice has a long tradition Czech Republic and introduction of IFRS has no impact on this tradition. 
it has become probable that future taxable profit will allow the deferred tax asset to be recovered. This rule, that is part of IAS 12 or FRS, is not incorporated into the Decree.

The last part of Decree, concerning deferred taxes, describes the procedure of deferred tax first time recognition. When accounting for a deferred tax for the first time, such part of deferred tax which related to previous accounting periods shall be charged to an account of account group 42 (Reserves, indivisible fund and retained earnings and funds created from net profit), and its part which relates to the current accounting period shall be charged to an account of account group 59. In subsequent years, only increase or reduction in deferred tax (asset or liability), calculated on all temporary differences which have arisen since the preceding period shall be posted to appropriate account of group 48 . In the case of a change in the method, the differences (arising there from) shall be charged to accounts of accounting group 42. It is not clear enough what kind of change in the method it is concerned.

The decree in the section called deferred tax method, as describes above, doesn't mention the manner and scope of deferred tax disclosure. There is only a single sentence of its section regulating disclosures in general, section four subsection 39; obligation to disclose detailed specification of deferred tax assets or deferred tax liability in notes on conditions that figures are not separately recognized in the balance sheet or income statements.

\subsection{Deferred taxes in Czech Accounting Standard}

Accounting regulation in the Czech Republic is realized by governmental institutions only. Tradition of professional independent accounting bodies was interrupted by forty years of communist regime. The consequences of the absence of the professional independent accounting bodies is that their position is either nil or very weak. The process of rebuilding accounting profession into the professional independent accounting body is rather slow. Moreover, the position of the independent accounting bodies in continental European accounting systems is lower and less importance in comparison with United Kingdom or USA. There are evidence, that instruments of regulatory systems of accounting are changed and institutions developing standards are changed as well as. Instruments of European accounting regulatory systems are mostly combination of elements of private and public 
standards setting even in those regulatory accounting systems, where this tradition does not exist. Traditionally, institutions developing accounting standards are independent professional accounting bodies, nowadays governmental agencies becomes standard setters and developed quasi standards. These regulatory accounting systems, where accounting system combines elements of private and public standards setting and independent professional accounting bodies with governmental institutions could be called hybrid regulatory ones (Žárová, 2007). Similar development of the primary hybrid regulatory accounting system will may to be expected in the Czech Republic as the article of the Act determines Ministry of Finance or any legal entity selected in public tender as a standard setter. This is historically the first moment when Ministry of Finance in the Czech Republic admits the possibility of existence a rule-making body that differs from Ministry of Finance.

Accounting systems, where development of standards and due process is described in the case of the Czech Republic and that is realized by the Ministry of Finance has several disadvantages. Accounting standards, in majority of cases, don't reflect economic transactions from every-day business life and therefore development of these standards aren't a natural consequence of "best practice". Standard setting process where there is an absence of correction from public suffer from defectiveness in different aspects (lack of responsibility for rule making process, poor understanding of accounting issues etc.). On the other hand there is a clear endeavor to implement IAS and IFRS into the Czech accounting standards developed by the Ministry of Finance. Good example of this process is standard No.3- Deferred tax.

Czech Accounting Standard No.3 is divided into three parts: Part number one is the aim of the standard. Part number two includes contents of the standard and part number three concerning accounting procedures.

The aim of this standard is to set out general procedures for accounting for deferred tax. This setting is in accordance with the Accounting Act (No 563/1991 Coll., as amended); and Decree on Accounting for Business (No. 500/2002 Coll., as amended);

General procedures are set for accounting and reporting deferred tax in items either "Deferred tax - receivable" or "Deferred tax - payable" (balance sheet items) and items "Income tax on ordinary activity deferred" or "Income tax on ordinary activity-deferred" and "Income tax on 
extraordinary activity - deferred" or "Income tax on extraordinary activity - deferred" (under the conditions pursuant to sections 3 and 4 of the Decree) with a view of harmonizing procedures applied by accounting entities.

Part two is entitled determination of contents. First subsection is about scope. The scope of the duty to account for deferred tax and fundamental procedures for its reporting are set down in section 59 of the Decree. Second subsection states that a tax liability which is deferred implies from differences which arise at the time when certain items in accounting are treated differently pursuant to accounting and tax legislation.

Third subsection concerns temporary differences. Differences which arise as a result of different accounting and tax treatment are of a temporary nature. Temporary differences can be:

a) taxable; such differences will result in taxable amounts on computing the tax base (taxable income) in future periods and give rise to a deferred tax liability (e.g. when the book value of a particular tangible fixed asset is higher than its value for tax purposes);

b) deductible; such differences will result in amounts that are deductible on computing the tax base (taxable income) in future periods and lead to a deferred tax asset (e.g. when the net book value of receivables, decreased by adjustments, is lower than the value of such receivables, including adjustments recognized for the tax purposes).

Fourth subsection: Deferred tax shall be computed on all temporary differences resulting from a different accounting and tax treatment of items shown in the books of account (accounting), that is not only on differences between the carrying value and the tax value of depreciable tangible and intangible fixed assets, but also on other differences (e.g. value adjustments to inventories, adjustments to receivables, provisions exceeding the statutory limits and unrealized loss from previous years). Even though the term temporary differences are not mentioned in accounting rules firstly, there is no explanation here neither in the decree, the higher level of accounting regulation. Financial statements prepares can only guess what temporary differences means and whether the definition is similar to IAS 12 or even the same as in IAS 12. Provided that the regulator decided to implement IAS 12 into Czech accounting system, there is one very important departure from IAS 12. 
Departure from IAS 12 arises from the statement that deferred tax shall be computed on all temporary differences resulting from a different accounting and tax treatment of items. This statement doesn't implies any exception from this rule. While the IAS 12 states that a deferred tax liability shall be recognised for all taxable temporary differences, except to the extent that the deferred tax liability arises from:

a) the initial recognition of goodwill; or

b) the initial recognition of an asset or liability in a transaction which is not a business combination; and at the time of the transaction, affects neither accounting profit nor taxable profit (tax loss).

A temporary difference may arise on initial recognition of an asset or liability, for example if part or all of the cost of an asset will not be deductible for tax purposes. Currently, it is necessary to be said that the method of accounting for such a temporary difference depends on the nature of the transaction that led to the initial recognition of the asset or liability. Theoretically, if the transaction is not a business combination, and affects neither accounting profit nor taxable profit, an entity would, in the absence of the exemption provided by (a) and (b) above, recognise the resulting deferred tax liability or asset and adjust the carrying amount of the asset or liability by the same amount. Such adjustments would make the financial statements less transparent. Therefore, the IAS 12 does not permit an entity to recognise the resulting deferred tax liability or asset, either on initial recognition or subsequently. Furthermore, an entity does not recognise subsequent changes in the unrecognised deferred tax liability or asset as the asset is depreciated. This part concerning exception from the rule Czech accounting standard is missing at all.

Fifth subsection is very short with finding on deferred tax liabilities. Deferred tax liabilities shall mean to be income tax amounts [resulting from the differences described in subsection three above to be settled in future periods.

Sixth subsection concerns deferred tax assets. Deferred tax assets shall mean to be income tax amounts to be claimed in future periods. Such deferred tax assets may arise from:

a) deductible temporary differences;

b) unused tax losses brought forward;

c) other unused tax allowances (deductibles) brought forward and other tax entitlements which are transferable to future periods. 
Seventh subsection is in compliance with IAS 12 and states that at the end of each reporting period, an entity reassesses unrecognised deferred tax assets. The entity recognises a previously unrecognised deferred tax asset to the extent that it has become probable that future taxable profit will allow the deferred tax asset to be recovered. At the balance-sheet day, the Czech accounting entity shall reassesses the carrying value of deferred tax asset, and if the taxable base is unlikely to attain the level which would enable the deferred tax asset to be claimed, either in part or in full, the carrying value of the deferred tax asset will be reduced. The scope of such reduction shall be made with regard to the expected attainable taxable income. The accounting entity shall state the previously non-disclosed deferred tax asset in the amount which is likely to be made use of (i.e. claimed) in future with regard to its expected profit.

Eight subsection splits deferred tax into deferred tax on ordinary activity and deferred tax on extraordinary activity. Ordinary activity comprises operating activity and financial operations.

Ninth subsection describes situation when deferred tax asset and deferred tax liability arise from different activities contemporaneously. If in one accounting period a deferred tax asset arise in respect of one activity (in the meaning of previous subsection) and a deferred tax liability arises in respect of the other activity, this fact must be disclosed in the income statement.

Tenth subsection sets the rule for offsetting. Deferred tax liabilities and deferred tax assets which have been booked (set off) in appropriate account of group 48 - Deferred tax - liability or asset shall be shown as the balance of this account provided that the conditions in the seventh subsection have been fulfilled.

Part three of the standard is entitled Accounting procedure. First subsection set rules for first time deferred tax adoption. When accounting for deferred tax for the first time, one part of deferred tax relating to previous accounting periods shall be posted to appropriate accounts of group 42 - Reserve funds, indivisible fund, other funds created from profit, and profit or loss brought forward and one part relating to the current accounting period shall be posted to appropriate accounts of account group 59 - Income tax expense, transfer accounts and income tax reserve. In subsequent years, only an increase or decrease in deferred tax, calculated on all temporary differences against the preceding period, shall 
be booked by means of appropriate account of group 48 - Deferred tax liability or deferred tax asset.

Second subsection describes changes of method. In the case of a method change (including a change in the way in which deferred tax is computed), differences arisen shall be posted to appropriate accounts of group 42 - Reserve funds, indivisible fund, other funds created from profit, and profit or loss brought forward, and the relevant item shall be explained in the notes to the financial statements.

Third subsection sets posting of deferred tax liability. Deferred tax liability is debited on appropriate account of group 59 - Income tax expense, transfer accounts and tax income reserve and by a credit entry in appropriate account of group 48 - Deferred tax - liabilities or asset.

Fourth subsection sets posting of deferred tax liability. Deferred tax asset is credited on appropriate account of group 59 - Income tax expense, transfer accounts and tax income reserve and by a debit entry in appropriate account of group 48 - Deferred tax - liability or asset. A deferred tax asset is posted only when it is likely that the tax base, on which the differences under subsection three in the second part can be made use of, is regarded realizable. A tax base is regarded realizable when there are sufficient taxable temporary differences relating to income taxes administered by the same tax administrator (financial office) and the same accounting entity in respect of which a refund is expected:

a) in the same period in which temporary deductible differences are expected; or

b) in periods in which a tax loss arising from a deferred tax asset (future receivable) can be claimed retroactively or brought forward to future periods.

Under these circumstances, a deferred tax asset is recognized into the period when temporary deductible differences arise.

Fifth subsection concerns the situation when the tax rate is altered. In the case that the income tax rate is altered, it is necessary to recalculate the balance in the account where deferred tax is followed and book the difference by means of appropriate account of group 59 - Income tax expense, transfer accounts and income tax reserve. 
Sixth subsection sets that temporary differences may arise in a business combination. Fair value adjustments and revaluation of assets in a business combination or capital investment will give rise to differences which will result in a deferred tax (Skálová - Čouková, 2009). The carrying value of assets shall be increased to the fair value but the tax base shall remain in the amount computed according to the original acquisition cost. Where differences in respect of such assets arise, the accounting entity shall include them in the calculation of deferred tax in the following way. In the case of items which are directly credited or debited against own equity (in acquiree's financial statements in business combination), a deferred tax shall also be directly posted as a credit or debit entry against own equity. In the case of capital investment, the acquiring accounting entity shall book a deferred tax liability by a corresponding entry in the account of retained earnings from previous years in group 42 - Reserve funds, indivisible fund, other funds created from profit, and profit or loss brought forward.

The goodwill is completely omitted in CAS. The topic of goodwill is important and for the purpose of goodwill recognition IAS 12 should be implemented. The topic of goodwill should be explained in the Czech standard, even if it is the case when goodwill has a tax base of nil. Any difference between the carrying amount of goodwill and its tax base of nil is a taxable temporary difference. However, the rules stated in IAS 12 does not permit the recognition of the resulting deferred tax liability because goodwill is measured as a residual and the recognition of the deferred tax liability would increase the carrying amount of goodwill (Pelák, 2009). Still, the reasoning of IAS 12 that goodwill was a residual and any increase in its carrying amount, resulting from the recognition of a deferred tax liability, would not have been appropriate, is understandable and with the related goodwill definition also conceptually defendable (Filinger, 2009). The stumbling block is that recognition of goodwill in Czech accounting differs from IFRS approach and deferred taxes arise from business combination are not allowed to be account directly to goodwill, but in compliance with CAS 3, into acquiree's equity.

Manner and scope of disclosures to the issue of deferred taxes are not involved in the Czech accounting standard as well as the fact that deferred tax assets and liabilities shall not be discounted in compliance with IAS 12. 


\section{Conclusion}

The article, investigating IAS 12 implementation into Czech accounting regulatory system, implies that IAS 12 implementation was realized in the Czech accounting only partially or incompletely, moreover even without the knowledge of the far-reaching consequences. Beside differences stated in the article, there is an absence of complete parts of investments in subsidiaries, branches and interests in joint ventures, measurement, recognition of current tax and deferred tax. There is also an absence of definitions: tax base of asset, tax base of liabilities, balance sheet approach of liability method, income statement of liability method, temporary differences, taxable temporary differences, deductible temporary differences. Moreover no reference to any rules or accepted accounting principles where the reader is allowed to study terms. IFRS partial implementation may even cause breakdown of the accounting system.

Ignorance of far-reaching consequences of accounting rules may bring entities to the court; moreover entities spent higher costs and may loose confidence by users of accounting information (Žárová - Mejzlík, 2009). As it was stated in the introduction to this article, in spite of the harmonization process, there may be systematically different patterns of accounting behavior applicable in particular country. Accounting entities, especially those owned by foreign companies or reported to parent ones, treat their transactions in compliance with fair regulations even if this treatment breaks Czech law for accounting. Consequence of this practice is that rules are used differently for treatment of the same cases..Different accounting treatment for the same case may bring complications to audit too. Preparers of financial statement, auditors and users too, often doubt whether to prefer substance of the transaction or legal consequence of the transaction.

Example of IAS 12 implementation into Czech accounting regulatory system, provide us clear demonstration of wrong philosophy how to reach comparable accounting information. Based on the criticism above, the recommendation is not to continue in partial IFRS implementation but make good rule for entities to allow them to choose either full IFRS or 
Žárová, M.: Impact of IAS 12 on Deferred Taxes Regulation in the Czech Republic.

domestic rules applicable in compliance with the approach "think small first"7 (Žárová, 2010).

\section{References}

[1] Filinger, M. (2009): Deferred tax and its conceptual complexities. Prague, University of Economics Prague, 2009, PhD. thesis.

[2] IASB (2009): International Financial Reporting Standards 2007. London, International Accounting Standards Board, 2009.

[3] Pelák, J. (2009): Právně-účetní problémy vlastního kapitálu. In: Vašeková, M. - Hora, M. (ed.). Účtovníctvo a audítorstvo v procese svetovej harmonizácie. Bratislava, Ekonomická univerzita, pp. 156159.

[4] Radebaugh, L. - Gray, S. - Black, E. (2006): International Accounting and Multinational Enterprises. New York, Wiley. pp 34, 2006.

[5] Skálová, J. - Čouková, P. (2009): Účetní a daňové dopady transakcí $v$ kapitálové společnosti. Praha, Wolters Kluwer ČR, 2009.

[6] Žárová, M. (2006): Regulace evropského účetnictví. Praha, Oeconomica, 2006.

[7] Žárová, M. (2007): Analysis of Hybrid Regulatory Accounting Systems. European Financial and Accounting Journal, 2007, vol. 2, no. 1 , s. 8-25.

[8] Žárová, M. (2008): Accounting Reform in the Czech Republic. In: McGee, R. W. (ed.): Accounting Reform in Transition and Developing Economies. Miami, Springer, 2008, pp. 89-100.

[9] Žárová, M. (2010): Dopad směrnice ES na vykazování účetních informací pro malé a střední podniky. Český finanční a účetní časopis, 2009, vol. 4, no. 3, pp. 73-77.

[10] Žárová, M. - Mezlík, L. (2009): Have IFRS positive impact on the regulatory accounting systems in continental European countries? European Financial and Accounting Journal, 2009, vol. 4, no. 1, pp. 5.

7 Communication from the Commission to the Council, the European Parliament, the European Economic and Social Committee and the Committee of the Regions "Think Small First" - and "Small Business Act" for Europe \{SEC(2008) 2101\} $\{\operatorname{SEC}(2008) 2102\}$. 


\title{
Impact of IAS 12 on Deferred Taxes Regulation in the Czech Republic.
}

\author{
Marcela ŽÁROVÁ
}

\begin{abstract}
This article investigates the impact of IAS 12 on deferred taxes regulation in the Czech Republic, where local accounting regulations includes accounting standards only by names, but not as an output of regular due process and which are not issued by the professional accounting body at all, not even partially. The article deals with the development and description of the Czech accounting system from early nineties of last century till present time as a background for IFRS implementation. Then the article followed subsequent steps of IAS 12 implementation into the hierarchy of legal rules for accounting, starting with the Act on accounting, decree on business entities and Czech accounting standard for deferred taxes.

IAS 12 implementation into Czech accounting system is an example of partial and incomplete implementation of IFRS into domestic accounting rules based on different law presumption than under which are IFRS developed.

Example of IAS 12 implementation into Czech accounting regulatory system, provide the reader clear demonstration of wrong philosophy how to reach comparable accounting information. Based on the published criticism, the recommendation is not to continue in partial IFRS implementation but make good rule for entities to allow them to choose either full IFRS or domestic rules applicable in compliance with the approach "think small first".
\end{abstract}

Key words: IAS 12; Deferred tax; IFRS implementation.

JEL classification: M41. 